\title{
Environmental risks, demographic dynamic and Life Quality. Argentina at beginning of XXI century
}

\author{
GUILLERMO ANGEL VELÁZQUEZ \\ Director Centro de Investigaciones Geográficas UNICEN. \\ Investigador Principal CONICET
}

\begin{abstract}
In this work we analyze the relationship among: 1) Certain environmental risks: Flood problems, Earthquakes, Tornadoes and Soil degradation, 2) Demographic dynamics (inter census growth and migratory balances) and 3) Grade of Life Level Quality of Argentinian people.

We use a Geographical Information System (GIS) in which we have done the digitalization of the respective layers of environmental risks. Following, we examine the information on demographic dynamics. At last, we present a synthetic index of the population's Life Quality, which was elaborated starting from a combination of weighted indicators of environmental and socioeconomic dimensions (education, health and housing).

The next step is to study the demographic behaviour and the grade of well-being of Argentina's people different segments for each one of the environmental risks. We start from an operation of overlapping of different layers (for example: flood risk, growth rate, migration balance, etc).

All previous stepladder let us size and compare the obtained Life Quality Index with Demographic Dynamics according to the degree of affectation of each one of the considered physical-environmental events.

Finally we can establish the future scenario by projecting these phenomena impacts into the process of global environmental change.
\end{abstract}

Key Words: Life Quality Index, Demographic Dynamic, Environmental Risks, Argentina

\section{Introduction}

In this work we will study the relationship among environmental risks (flood problems, earthquakes, tornadoes and soil degradation), demographic dynamics (intercensus growth and migration balances) and the life quality level of Argentinian people.

We will use a GIS in which we have done the digitization of the respective layers of environmental risks. Then, we will be prepared, in the following point, to examine the information on demographic dynamics for, at last, present a synthetic index of the population's life quality, which was elaborated starting from a combination of weighted indicators of environmental and socioeconomic dimensions (education, health and housing). 
In the following step, we will be able to determinate the demographic behaviour and the grade of well-being of Argentina's people different segments for each one of the environmental risks, starting from an operation of overlapping of layers.

All previous steps will let us size and compare the life quality level and the demographic dynamics according to the grade of affectation of each one of the considered physical-environmental events. This will also let us establish the scenery for the projection of these phenomena into the process of global environmental change.

\section{Migratory dynamics in Argentina through different development stages}

Argentina, during the "agriculture-exporter stage" (1880-1937), evidenced already a high character of regional inequality. The most eloquent sample of this was the preeminence of the port and the humid pampas for all over the rest of the territories. The European migratory contingents then resided predominantly in Buenos Aires and Pampean region, also contributing to the increment of regional differentiation.

The following period, "import substitution process" (1937-1976), instead of reverting this situation, it increased the industrial concentration in the Pampean big cities. Although the external migratory contingents were not as significant as in the previous stage, there were internal and bordering migrations that contributed also to the process of demographic and economic concentration in the Pampean region.

Since the period of "social fragmentation" (from the military dictatorship up to the ninety years) Argentina, except for particular joints, has diminished their capacity to attract and it begins to suffer their own population's exodus, in growing form, towards North-America, Europe, Australia, the most, and, inclusive, towards bordering countries as Brazil. From 2003 this tendency seems to have been reverted, verifying return people processes.

The internal migrations in Argentina have been of considerable magnitude. The importance of these movements was growing up to 1960-1970 and then it began to descend. It is calculated that from 1895 about 8 million people changed their resident country and that these migrations had affected both, the push and pull areas.

Until 1914 the migratory currents between neighbourhood counties prevailed; from 1914 to 1947 a transition takes place; and during the lapse contained into the 1947 and 1970 censuses the most of the migratory flows have as destination place the Buenos Aires Metropolitan Area (AMBA), whatever the distance to that place is. In the late 1970 's and, especially along the following decade, a decrease of the internal migrations takes place, producing a significant tendency change in these movements, which now are reoriented preferably towards the middle size cities.

Lattes and Sana (1992) estimate that the redistribution for inter-counties migrations reached to $1,108,000$ people (1960-1970), to 639,000 (1970-1980) and to 441,000 (1980-1991). They determinate that the female population has a growing weight on these migrations. So, women had superior rates than men in 2 counties during 1960-1970, in 4 between 1970-1980 and in 9 during 1980-1991.

Traditionally, internal migrations have taken place in stages: from the rural area to small towns; at the second, to regional centres (local or regional ones); at last, to big 
cities (national level). When the 1970's were finishing this last stage was diluting, augmenting the peripheral of middle size cities. (Liberali, Morina and Velázquez, 1989).

Occupation, stratification and quality of life indicators contribute to explain the emigration phenomena. Between 1947 and 1960 the importance of employment indicators stands out; while starting from the 1960's it the life quality aspects seems to acquire bigger significance in order to explain migratory flows.

It is highly probable that tendencies of growth and internal migration observed along the last decades continue up to the present time and in the near future. In this perspective, Argentina of the Bicentenary (2010-2016) will have smaller rate of demographic growth, with smaller inter-county migration and smaller territorial concentration, too.

Lattes (2007) points out that this observation doesn't mean that today the territorial mobility of people has diminished; on the contrary, there are indications about the proliferation of space movements of short duration and very different, including migration for shorter periods.

Some authors mention it as the end of migrations, others highlight that the individuals are changing their activities more frequently, but this doesn't imply population's massive space movements. Other authors highlight the increase of the territorial movements of individuals and families, for short periods and between more than one residence places. Others refer to these growing population displacements, inside and among nations, like forced by diverse kinds of catastrophes. Hobsbawm (2000) expressed "The news is that, among production factors, the human beings are less necessary each time: the human beings are not suitable for the capitalism".

Table 1 Population growth by counties: Total, Natural Increase and Migration Balance

\begin{tabular}{|l|c|c|c|c|c|c|}
\hline $\begin{array}{l}\text { Argentinean } \\
\text { Counties }\end{array}$ & \multicolumn{3}{|c|}{$1980-1990$ (Growth Rate \%o) } & \multicolumn{2}{c|}{ 1990-2000 (Growth Rate \%o) } \\
\hline & Total & $\begin{array}{c}\text { Natural } \\
\text { Increase }\end{array}$ & $\begin{array}{c}\text { Migration } \\
\text { Balance }\end{array}$ & Total & $\begin{array}{c}\text { Natural } \\
\text { Increase }\end{array}$ & $\begin{array}{c}\text { Migration } \\
\text { Balance }\end{array}$ \\
\hline Buenos Aires & 14 & 12 & 2 & 11 & 10 & 2 \\
\hline Capital federal & 1 & 3 & -2 & 0 & 1 & -1 \\
\hline Catamarca & 22 & 18 & 4 & 25 & 21 & 4 \\
\hline Chaco & 17 & 24 & -7 & 16 & 21 & -4 \\
\hline Chubut & 28 & 22 & 7 & 19 & 17 & 1 \\
\hline Córdoba & 13 & 13 & 0 & 12 & 11 & 1 \\
\hline Corrientes & 17 & 21 & -5 & 17 & 20 & -3 \\
\hline Entre Ríos & 11 & 16 & -5 & 13 & 14 & -1 \\
\hline Formosa & 27 & 25 & 2 & 22 & 24 & -2 \\
\hline Jujuy & 21 & 25 & -4 & 19 & 20 & 0 \\
\hline
\end{tabular}




\begin{tabular}{|l|c|c|c|c|c|c|}
\hline La Pampa & 20 & 15 & 5 & 17 & 14 & 3 \\
\hline La Rioja & 27 & 21 & 5 & 30 & 21 & 9 \\
\hline Mendoza & 16 & 17 & -1 & 13 & 15 & -2 \\
\hline Misiones & 26 & 26 & 0 & 22 & 24 & -2 \\
\hline Neuquén & 43 & 25 & 18 & 26 & 21 & 5 \\
\hline Rio Negro & 27 & 21 & 6 & 13 & 17 & -3 \\
\hline Salta & 25 & 27 & -2 & 23 & 22 & 2 \\
\hline San Juan & 12 & 19 & -7 & 16 & 17 & -1 \\
\hline San Luis & 26 & 16 & 10 & 28 & 18 & 10 \\
\hline Santa Cruz & 42 & 23 & 19 & 31 & 21 & 10 \\
\hline Santa Fe & 12 & 10 & 1 & 9 & 10 & -1 \\
\hline S. del Estero & 11 & 21 & -9 & 18 & 18 & -1 \\
\hline T. del Fuego & 42 & 23 & 19 & 31 & 21 & 10 \\
\hline Tucumán & 15 & 20 & -5 & 17 & 16 & 0 \\
\hline
\end{tabular}

Source: Lattes (2007) 


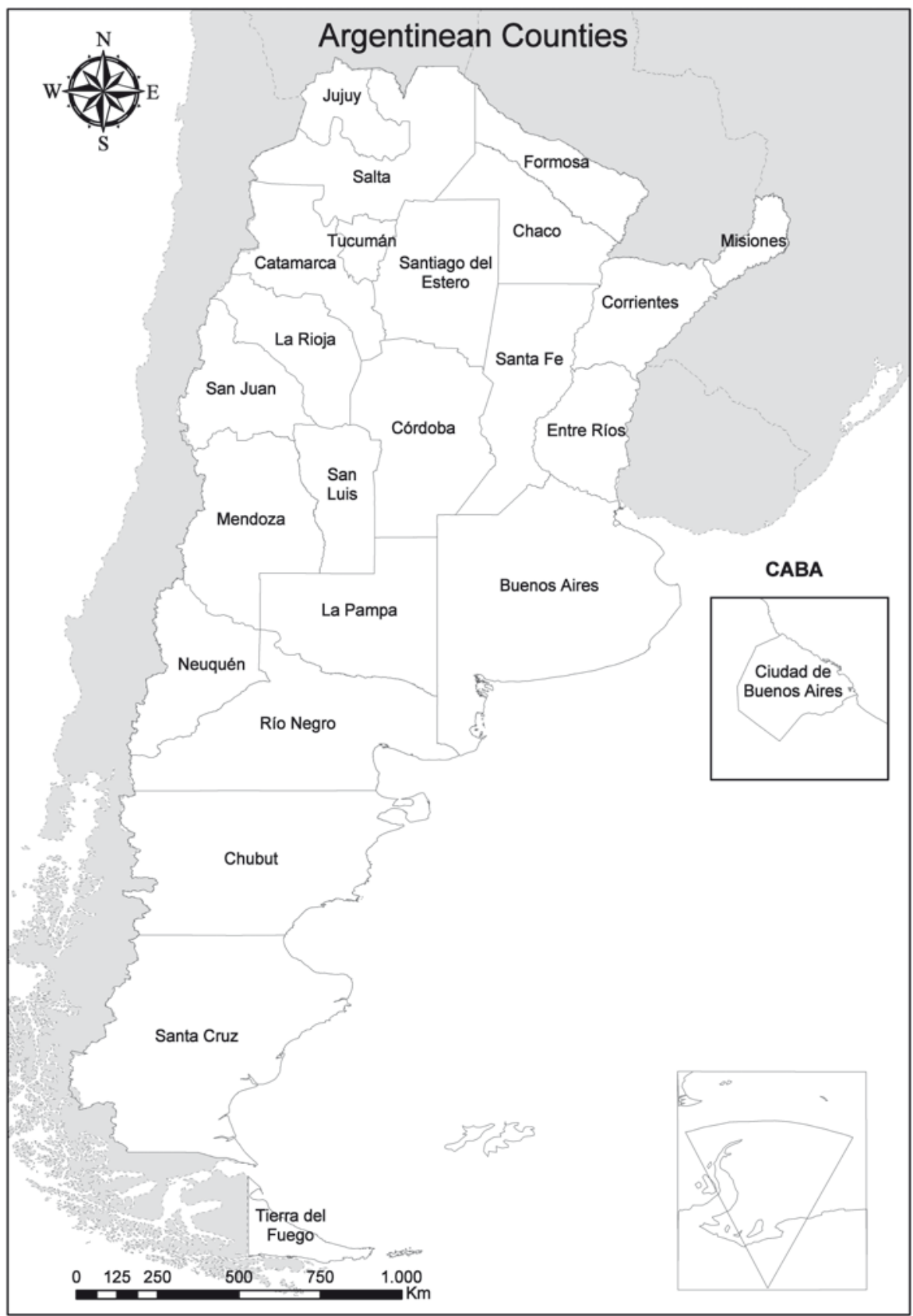

Fig. 1 Argentinean Counties 


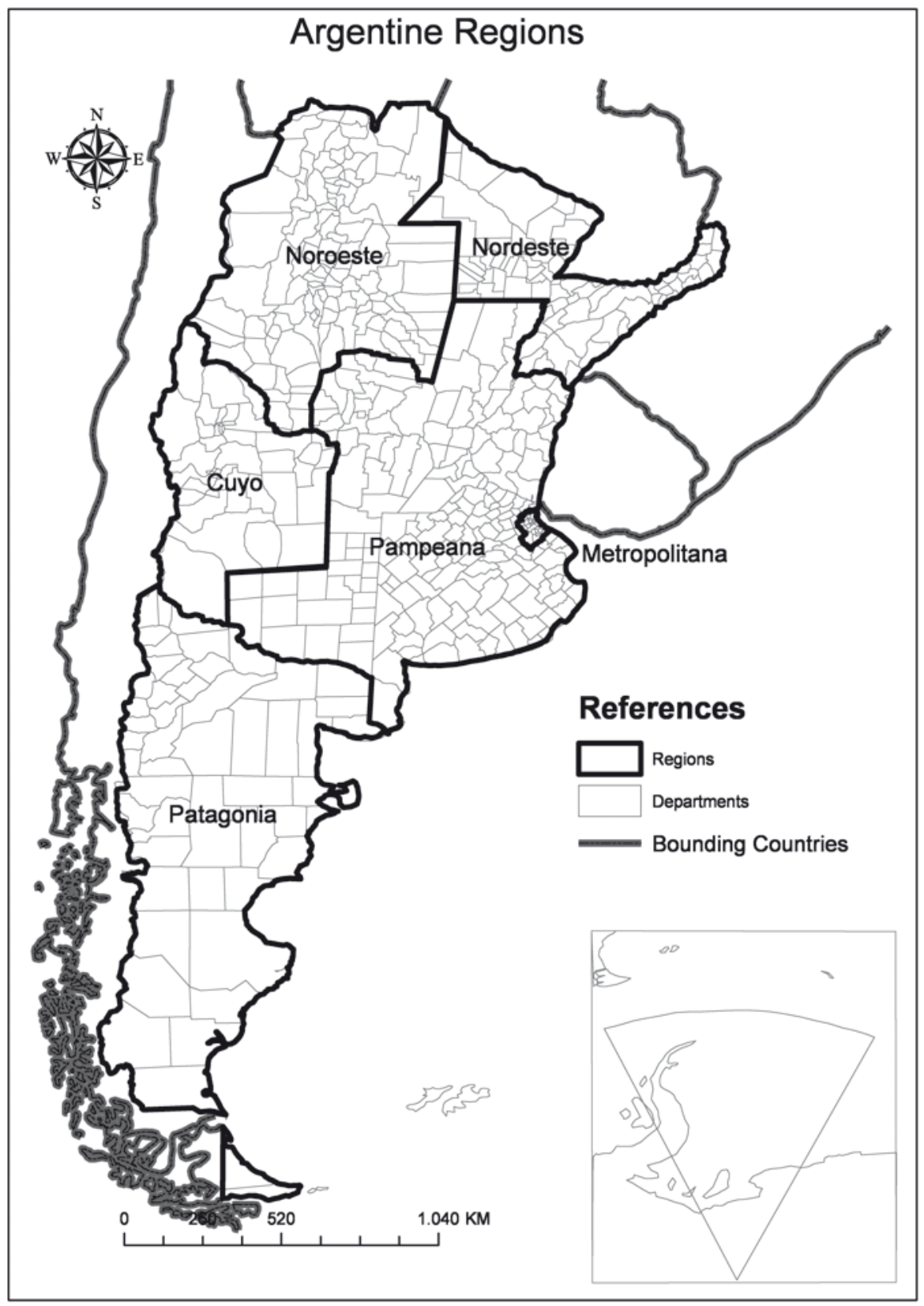

Fig. 2 Argentine Regions 


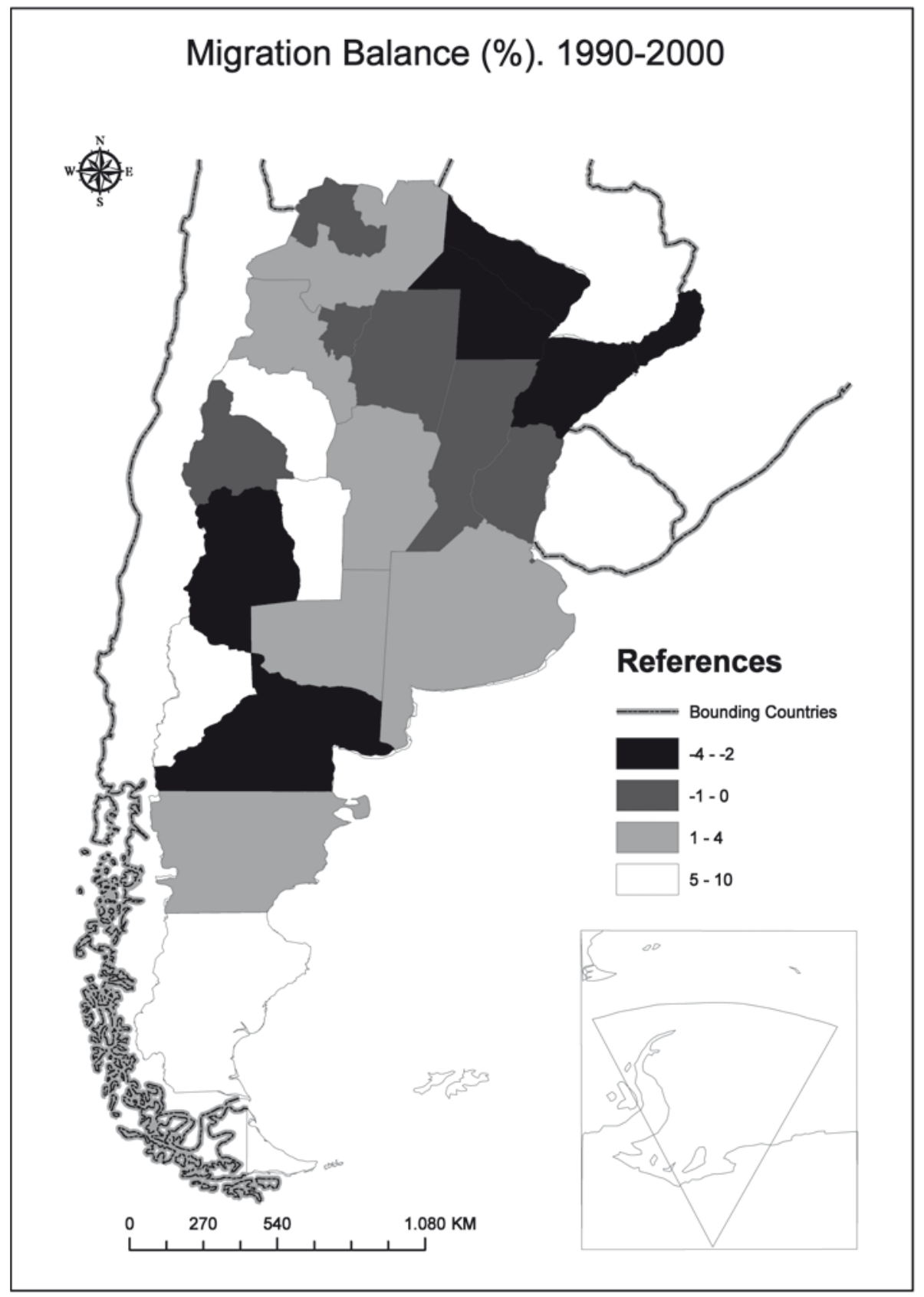

Fig. 3 Migration Balance 1990-2000 


\section{Life quality in Argentina: construction of an index}

The adjusted definition of an "objective" life quality index is neither simple nor a universally valid task. As result of our own experiences and also in previous papers broadly discussed in specific meetings ${ }^{1}$, we have used, to estimate LQ levels of Argentinian, by one hand, the socioeconomic dimensions of education, health and housing; and for the other one, environmental conditions and attraction of landscape. Educational Dimension:

- \% population with educational degree smaller to complete primary education (Table 7.82001 Census),

- \% population with complete university educational degree (Table 7.82001 Census). Health Dimension:

- \%o infantile death according to place of the mother's residence for the years 2000, 2001 and 2002 (Ministry of Health),

- \% population without covering for social work, private or mutual plan of health (Table 6.3 2001 Census).

Housing and Equipment Dimension:

- \% population that resides in housings with lack of exclusive use of toilets (Table 4.6 2001 Census),

- \% population in crowded homes, considering those that overcome 2 people for each room (Table 4.8 2001 Census).

Environmental risks and attraction of the landscape:

- \% homes located in areas with flood risk problems,

- \% population residing in earthquake areas,

- \% population residing in areas affected by tornadoes,

- \% population residing in areas with soil degradation,

- \% weekend and vacation housings (Table 3.42001 Census).

Dimension health is the most important component in the index. It is followed by housing, environmental risks and educational variables. The relative weight of each variable in the proposed index is the following:

\begin{tabular}{|c|c|c|c|}
\hline Dimension & Variables & Partial Weight (\%) & Total Weight (\%) \\
\hline Education & Pop < Primary & 10 & \\
\hline & PopUniversity & 5 & 15 \\
\hline Health & IDR & 20 & 35 \\
\hline & PopWithoutCovering & 15 & \\
\hline Housing & PopWithoutToilet & 20 & 30 \\
\hline & CrowdedHomes & 10 & 20 \\
\hline Environment & EnvironProblems & 15 & $\mathbf{1 0 0}$ \\
\hline & VacationHousings & 5 & \\
\hline Total & & & \\
\hline
\end{tabular}

\footnotetext{
Mainly Latinoamerican Netwok Researchers about Urban Quality of Life, meetings about Population and Quality of Life in "Jornadas Argentinas de Estudios de Población" and "Seminario Internacional sobre Población y Sociedad en América Latina” (SEPOSAL).
} 
Considering the relative weight of each variable we determined a Life Quality Index (LQI) whose theoretical value can reach between 0 and 10 to reflect the worst and better situation, respectively.

\section{Natural risks, demographic dynamics and life quality}

We will analyze the relationship among some environmental risks (flood risk, earthquake, tornadoes, and soil degradation) in connection with LQ conditions and demographic dynamics in Argentina. We'll use for it the adjusting power of information characteristic of Geographic Information Systems (GIS). The results will be shown in the followings tables 2 at 5 .

Table 2 Relationship among flood risk, Life Quality Index (LQI), and demographic dynamic

\begin{tabular}{|l|c|c|c|c|}
\hline $\begin{array}{l}\text { Flood risk } \\
\text { (\% homes by quartiles) }\end{array}$ & LQI & $\begin{array}{c}\text { Pop. } \\
\text { (millions) }\end{array}$ & $\begin{array}{c}\text { \% Growth Rate } \\
\mathbf{1 9 9 1 - 2 0 0 1}\end{array}$ & $\begin{array}{c}\text { Migration Balance } \\
\mathbf{1 9 9 0 - 2 0 0 0} \text { (\%) }\end{array}$ \\
\hline Low (0.0-4.67) & 7.08 & 5.07 & 13.33 & 0.13 \\
\hline Middle-low (4.68-8.71) & 6.95 & 8.97 & 12.32 & 0.04 \\
\hline Middle-hight (8.72-17.86) & 6.62 & 10.60 & 18.12 & 0.02 \\
\hline Hight (17.87-76.94) & 6.32 & 8.84 & 12.21 & -0.01 \\
\hline
\end{tabular}

This table reveals that the most affected quartile, with high flood risk (17.87 to 76.94\%) belongs to following regions: 1) Railroad Salta-Jujuy, 2) East of ChacoFormosa, North of Santa Fe and "Bajos Submeridionales", 3) Depression of rivers Salado-Vallimanca, in the Pampean region and 4) Buffers of rivers Matanza and Reconquista, in Buenos Aires surroundings. These areas summarize 8.84 million inhabitants. Buffers of Rivers Matanza and Reconquista region is the most populated. Depression of rivers Salado-Vallimanca region, on the other hand, possesses very low population density. This group, with hight flood risk, in connection with the LQ, shows a worse situation (index 6.32) than the remaining categories.

The areas 1 (Railroad Salta-Jujuy) and 2 (East of Chaco-Formosa, etc.) are spaces with very small rural property owners "campesinos" that, without means of subsistence, are compelled to migrate towards nearer middle size cities (Salta, Jujuy, CorrientesResistencia), expanding the respective urban peripheries. The flood risk can constitute an entire strategy of survival for riverside populations of these areas. The recurrent character of flood and drought periods makes them, at least a great portion, to assume the category of "flooded people" like a right for asking for shelter and attendance from State authorities. On the other hand precarious housings in flooded valleys reaffirm this vicious circle of "clientelismo asistencialista" (customer of social assistance). When "engineer solutions" are offered, the original population finishes to be displaced, since they haven't got the means to support or to acquire new housings. In most cases embankments are built around to preserve the urban areas; this solution makes the conditions of rural population even worse. 


\section{Flood Risk. Argentina, 2001}

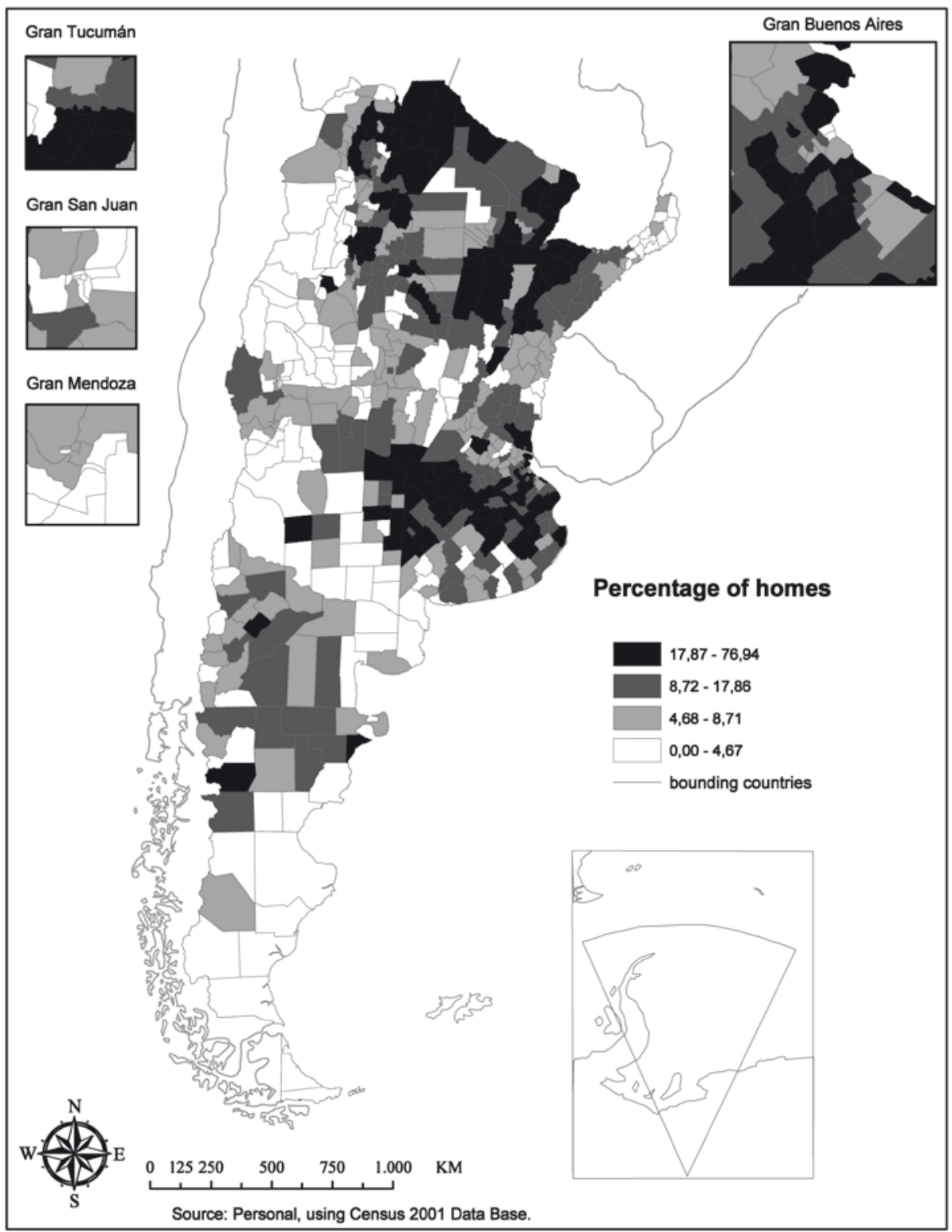

Fig. 4 Flood Risk, Argentina, 2001 
The area 3 (Depression of river Salado-Vallimanca) is characterized by the predominance of livestock towards the east, and of hibernation towards the west, always preserving the "private property" by wiring it. Its characteristic landscape is extremely plain and monotonous, only interrupted by forested areas and some little lakes. Some important lagoons stand out whose salinity increases towards the west. These lagoons constitute an attractive view, but in some cases they are threatened by a filler process and evaporation because of their vegetation. Topography problems, scarce infiltration, alternation of floods and droughts, and invasion of overgrowths are made worse because of the obstacles generated by the society and the absence of effective technical solutions. Another important problem is the inadequate application of insecticides and pesticides, since these noxious chemical substances accumulate and they infiltrate in the phreatic layers, affecting especially the population's health. Organchlorinated and organ-phosphorus are used so much in order to protect the bovine and sheep livestock. The people who work on this field are almost illiterate and cannot take into account the indications and cautions written in the containers that, once used, in many cases, are heady directly to the river (Liberali et al., 1996).

Still analyzing the river Salado-Vallimanca region, we can affirm that for these and other reasons, the depressed pampas have the smallest life expectancy into Buenos Aires County (Otero, Velázquez, 1995). In spite of the relevance of these problems, the worst one in the difficulties is derived of the scarce diversification and bad distribution of the means of production (basically land), characteristic of an economic and social traditional structure. This is combined with all the previous factors and it constitutes an invitation to emigrate or to accept an early and marginal incorporation to the economically active population. Who are satisfied with little, accept this last option, and they are able to subsist as rural peons or to live of "changas" (sporadic and badly paid jobs). Other options as, public work, installation of a small trade or autoemployment, are very restricted.

Finally, we'll characterize the area 4, basins of rivers Matanza and Reconquista, inside Buenos Aires's surroundings. The flooding risk takes bigger importance in this context for the towering population density. The expansion (the planned and the informal) of the city makes diminish the infiltration and the glide is increased. It is added to weak slope and finishes forming true "dams" in the areas of smaller bench mark. Some technical elements contribute to increase the previous problems. This way the sewer system of streams, the construction of embankments, the inadequacy of the existent deposits and the lack of green spaces even increase the population's vulnerability. Starting in the nineties, the privatization of the company that distributes and processes drinking water (Obras Sanitarias de la Nación) takes place, the new firm reduced costs extracting water directly from Río de la Plata, being increased this way the level of the phreatic layers and, therefore, the flood risk in some sectors of the conurbation.

Although the problem affects, to low revenues sectors, in some cases it is also suffered (although with smaller frequency) by other social stage, inclusive inside Buenos Aires City.

There are other 10.6 millions that also suffer flood risk problem in non despicable proportions (17.86 to $8.72 \%$ of their homes), besides the 8.84 million Argentinians 
who live in areas with higher flood risk problems. We could consider only 5 millions in a satisfactory situation (Argentina had almost 36 millions inhabitants in 2001).

Table 3 Relationship among earthquake, Life Quality Index (LQI), and demographic dynamic

\begin{tabular}{|l|c|c|c|c|}
\hline Earthquake risk & LQI & Pop. (millions) & $\begin{array}{c}\text { \% Growth Rate } \\
\mathbf{1 9 9 1 - 2 0 0 1}\end{array}$ & $\begin{array}{c}\text { Migration Balance } \\
\mathbf{1 9 9 0 - 2 0 0 0} \text { (\%) }\end{array}$ \\
\hline None & 6.63 & 23.16 & 12.37 & 0.69 \\
\hline Low & 7.09 & 3.79 & 16.50 & 1.17 \\
\hline Middle & 6.61 & 3.78 & 22.45 & 1.37 \\
\hline Middle-high & 6.84 & 2.37 & 16.40 & 0.34 \\
\hline High & 6.33 & 0.04 & 17.31 & -1.01 \\
\hline
\end{tabular}

As García points out (in Velázquez, 2001), earthquake phenomena are presented in Argentina almost exclusively with earth tremors affecting the boundaries of Andean borders and near areas to the mountains. These telluric movements affect the population summoned in their cities and inhabited areas, mainly in San Juan and Mendoza; and, in Salta and Jujuy in smaller scale. It is an aspect of the physical environment that causes human risk and lost of housings, infrastructure etc; whose relationship with the LQ of people is undeniable.

Although from the late $\mathrm{XX}^{\text {th }}$ century, earthquakes have had smaller intensity and appropriate constructions have been built, but it is known very little about their relationship with indicators of demographic dynamics and LQ in Argentina. ${ }^{1}$

As we see in the table, in the areas with higher earthquake risk, they register the worst levels of LQ (index 6.33). It is also prominent that, in spite of registering a middle demographic growth, these areas (although barely inhabitated) pull population. The departments with bigger repetition and graveness of the earthquake activity are: Rivadavia, Angallo, Chipas, Zonda, Ullum, Pocitos and Sarmiento (San Juan), and Las Heras, Godoy Cruz and Capital (Mendoza).

In middle-hight level of earthquake risks are: 25 de Mayo, Valle Fértil and Iglesia (San Juan); Lavalle and Rivadavia (Mendoza) and sectors of the counties of Jujuy and Salta. In these areas, the surface and the affected population is bigger (2.37 million inhabitants), without registering changes in their life conditions (index 6.84) or in their migratory dynamics (MR 0.34). The biggest grade of danger is registered around San Juan's capital for its high demographic density.

In middle level, we can find the departments of Maipú, San Martín, Guaymallén and Junín (Mendoza) as well as San Antonio, Palpalá, San Pedro and El Carmen (Jujuy) or those as Guemes, La Caldera, Capital, Cerrillos and Anta (Salta). This extensive area has diverse conditions of life (index 6.61), but sample high demographic growth (22.45\%) and high population's reception, too (MR 1.37).

Lastly, the areas with very low or null level of earthquake risk are located, in general, in the plains of Argentina's east and near areas to older geologic structures of

2 Historically this eartquakes had take levels of destruction of cities. By example, the cases of Mendoza (1861), San Juan (1944), and Caucete (1977). 
the centre and south. Both concentrate the biggest proportion of population number (almost 30 million inhabitants) and, despite a strong level of fragmentation, the best global conditions of life (index 6.63 and 7.09). Their demographic dynamics is a positive one (MR 1.17 and 0.69), but its rate of demographic growth is intermediate, basically for the high proportion of urban population and its relatively high educational level.

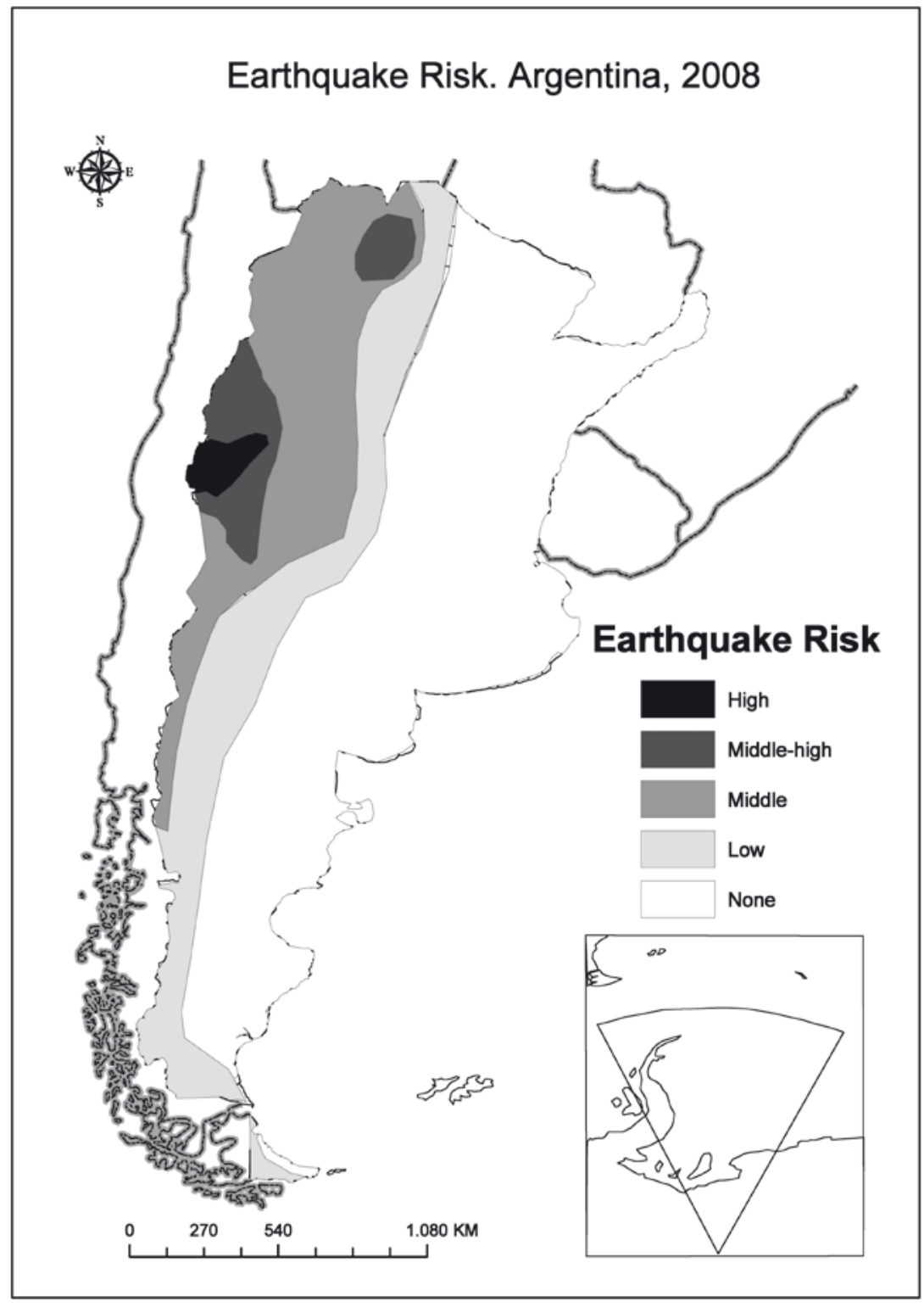

Fig. 5 Earthquake, Argentina, 2008 
Table 4 Relationship among tornadoes, Life Quality Index (LQI), and demographic dynamics

\begin{tabular}{|l|c|c|c|c|}
\hline Tornadoes & LQI & Pop. (millions) & $\begin{array}{c}\text { \% Growth Rate } \\
\mathbf{1 9 9 1 - 2 0 0 1}\end{array}$ & $\begin{array}{c}\text { Migration Balance } \\
\mathbf{1 9 9 0 - 2 0 0 0} \text { (\%) }\end{array}$ \\
\hline Null & 6.92 & 9.27 & 18.67 & 1.33 \\
\hline Scarce & 6.55 & 18.08 & 11.64 & -1.11 \\
\hline Frequent & 7.25 & 7.57 & 8.79 & 1.51 \\
\hline Very frequent & 7.34 & 1.18 & 6.82 & 1.18 \\
\hline
\end{tabular}

García affirms (in Velázquez, 2001) tornadoes and high-intensity winds are habitual phenomena in a large part of the national territory. They whip with devastating intensities affecting mainly to areas located in the northwest of the Pampean plain. This way, and although they are not very frequent phenomena, every time that it happens, in their short way (many times they only remain during some minutes) reach to destroy houses, facilities, crops and produce damage in the urban and rural areas that affect.

Although the biggest intensities and frequencies are located in the Northwest of Pampean region, in certain events they originate movements of whirls that end up moving outside this area, travelling several kilometres until they end up losing intensity.

The most affected departments are Gral San Martin, Unión and Marcos Juárez (Córdoba); and Gral Villegas, Carlos Tejedor, Rivadavia, Lincoln, San Justo and Gral Pinto (Buenos Aires). These areas, however, registers very good conditions of life (index 7.34) and have more than 1 million inhabitants.

In a second order, frequent affectation by tornadoes, we have a vast sector of Pampean region, also with good LQ level (index 7.25), but much more populated (7.57 million inhabitants).

Most people (almost 30 millions of Argentinian) live in areas where this phenomenon is scarce or null.

Table 5 Relationship among soil degradation, Life Quality Index (LQI), and demographic dynamic

\begin{tabular}{|l|c|c|c|c|}
\hline $\begin{array}{l}\text { Soil degradation } \\
\text { level }\end{array}$ & LQI & Pop. (millions) & $\begin{array}{c}\text { \% Growth Rate } \\
\mathbf{1 9 9 1 - 2 0 0 1}\end{array}$ & $\begin{array}{c}\text { Migration Balance } \\
\mathbf{1 9 9 0 - 2 0 0 0} \text { (\%) }\end{array}$ \\
\hline None & 6.48 & 1.17 & 14.90 & 0.48 \\
\hline Light & 6.67 & 19.11 & 16.00 & 0.10 \\
\hline Moderate & 6.77 & 8.46 & 14.72 & 1.12 \\
\hline Severe & 6.94 & 7.25 & 9.93 & 0.55 \\
\hline Very severe & 4.43 & 0.03 & 13.75 & 1.95 \\
\hline
\end{tabular}

Vast extensions of soils in Argentina have been deteriorated (with alterations under their balancing conditions), until arriving to the point of accelerating processes of lost of soil, due to the application of non appropriate use systems, as García points out (in Velázquez, 2001). 


\section{Tornadoes. Argentina, 2008}

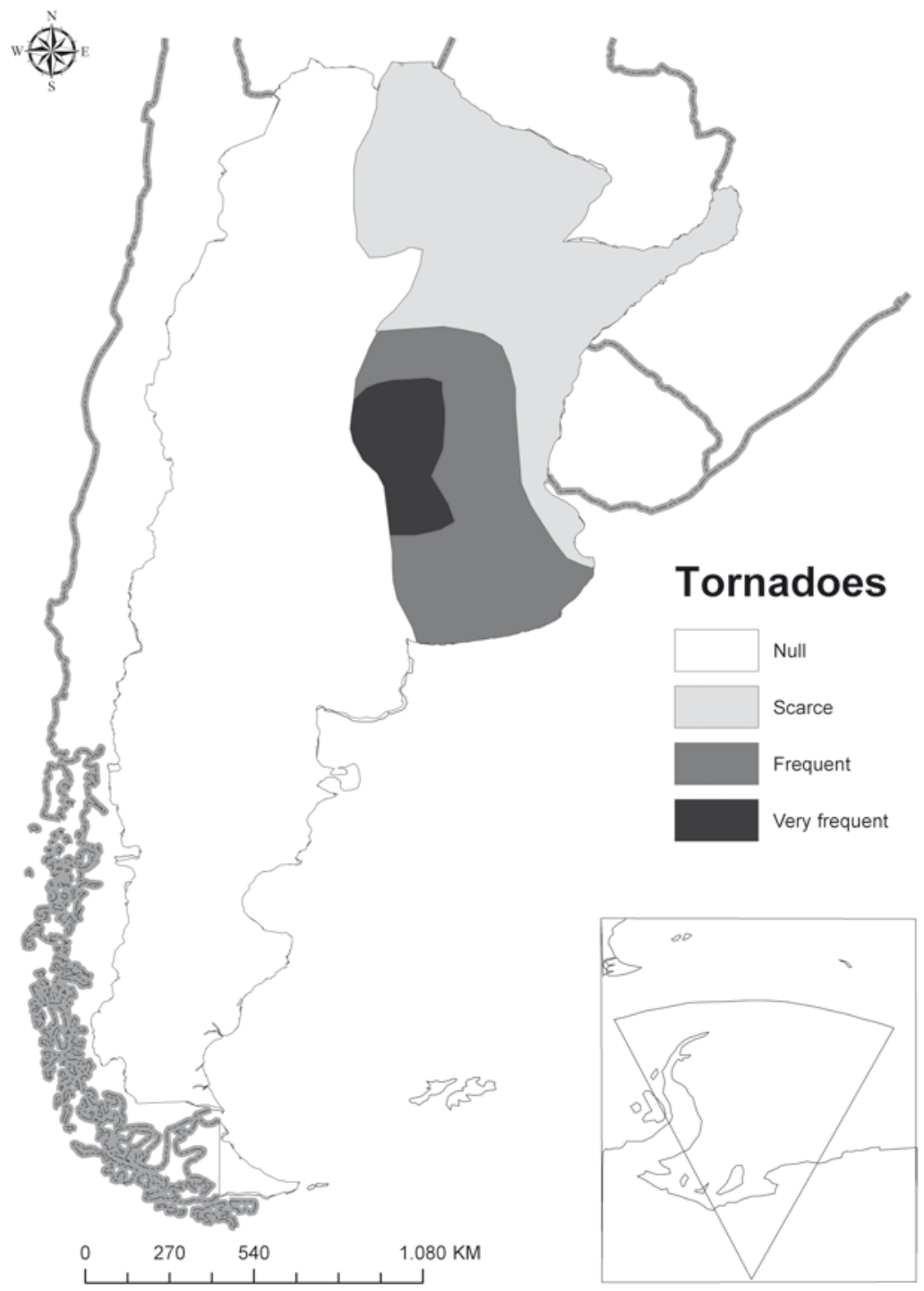

Fig. 6 Tornadoes, Argentina, 2008 


\section{Soil degradation. Argentina, 2008}

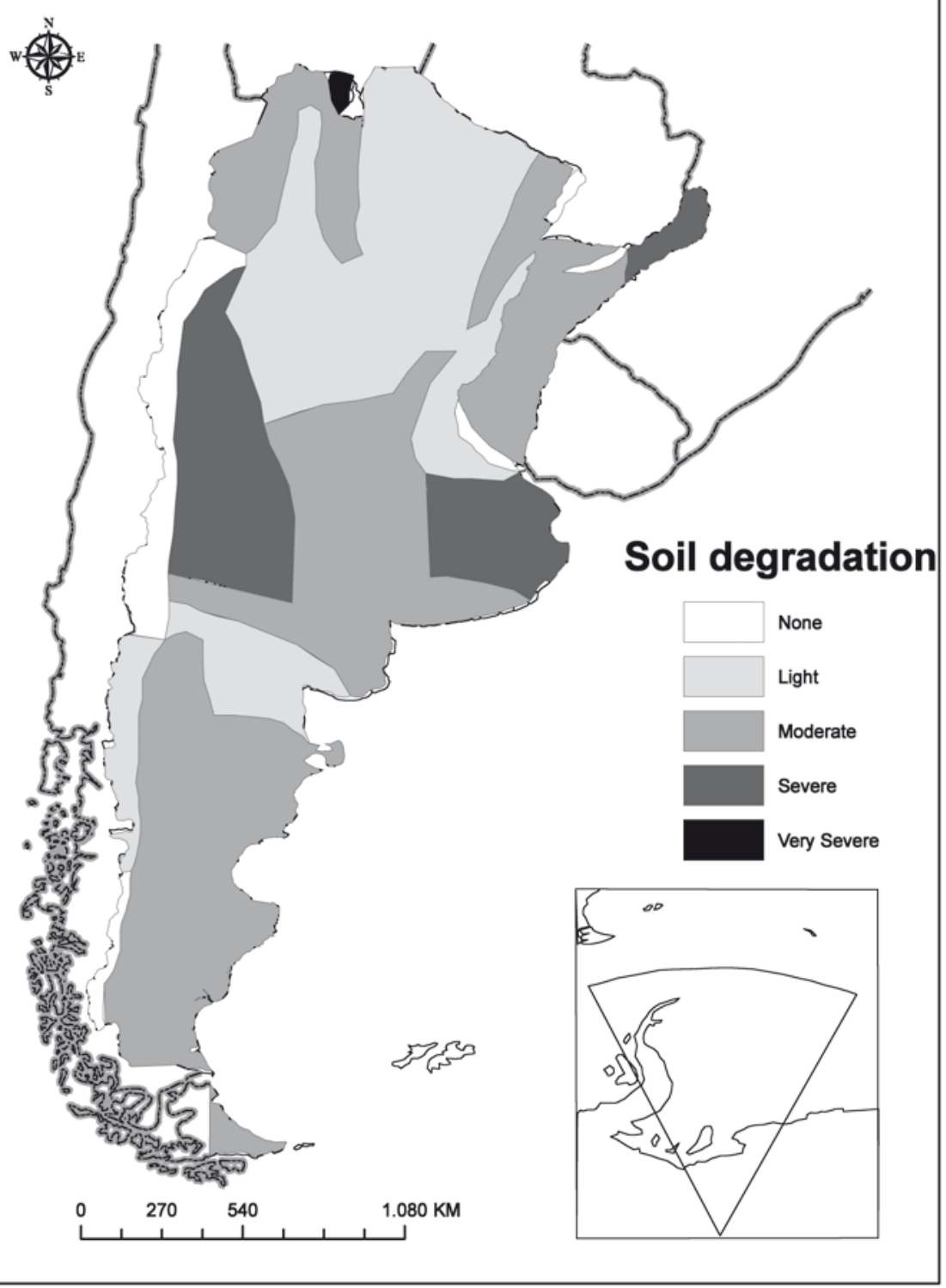

Fig. 7 Soil degradation, Argentina, 2008 
The most extreme case (very severe) is presented in north sector of Salta-Jujuy, barely populated, but that presents severe deficiencies in LQ (index 4.43). This phenomenon can be increased by virtue of the positive migratory dynamics of this area (MR 1.95) that can press more for a "mine" use of soil.

Inside the areas with severe degradation we have: 1) Oasis Cuyo and Patagonia Valleys, 2) Basin of river Salado-Vallimanca and 3) Misiones plateau. A great group of population (more than 7 millons) is affected with problems of severe erosion.

1) In the sector of Oasis Cuyo and Patagonia Valleys the problem of excess of salt in soils is bound mainly to the watering handling applied in arid or humid areas of scarce pending and bad drainage operation. The watering application in environments where the evapo-perspiration processes quickly, it implies many times the useless of productive soils of these regions due to excess of salt. The problem becomes bigger by the competition between urban soil uses and rural production inside the same productive areas, mainly because both activities need water as a resource for its development.

2) In the case of the sink of River Salado, we find an extensive region lacking of pending and made up by soils that impede the infiltration. In this geo-morphological region the climate and processes have let that before each flood, the waters are late in to be slippery and to evaporates, so after these phenomena, they left a lot of salt in soils. The over-shepherding, on the other hand, increase the erosion phenomena.

3) In the sector of Misiones plateau the use of soil has changed dramatically in the last 30 years, vast forest extensions have been replaced by plantations. These changes are more severe still in the neighbouring Brazil and Paraguay.

A significant portion that is presented in the erosion scales "moderate" or "light" is subjected to a regime of "mine" exploitation by virtue of imposition of the pattern of transgenic agriculture. This new modality, dedicated fundamentally to the export (for the backwardness in the Argentinean monetary type and the high international price), comes razing with another pre-existent productions.

The application of "technological packages" with trans-genetic seeds and bio-cidal chemicals like "glifosato" is showing alarming results, not only concerning to biodiversity lost and soil degradation, but fundamentally concerning to the Argentinian self-sufficiency food.

The rural owners lock out between March and June 2008 showed with cruelty the unavailability of a development model that considers soil like mere merchandise and the Argentinian like cheap workers and marginal consumers. After the government decision of putting up the rate for soy exportation applying bigger rates in function of the increments of the international price (mobile retentions) they spread a brutal blockade and food lacking to the domestic market, putting in check these intents of richness redistribution.

This phenomenon of "sojización" (expand of soy) is, therefore, one of the big social and environmental uncertainties of Argentina at the present time. 


\section{Life Quality Index. Argentina, c. 2001.}

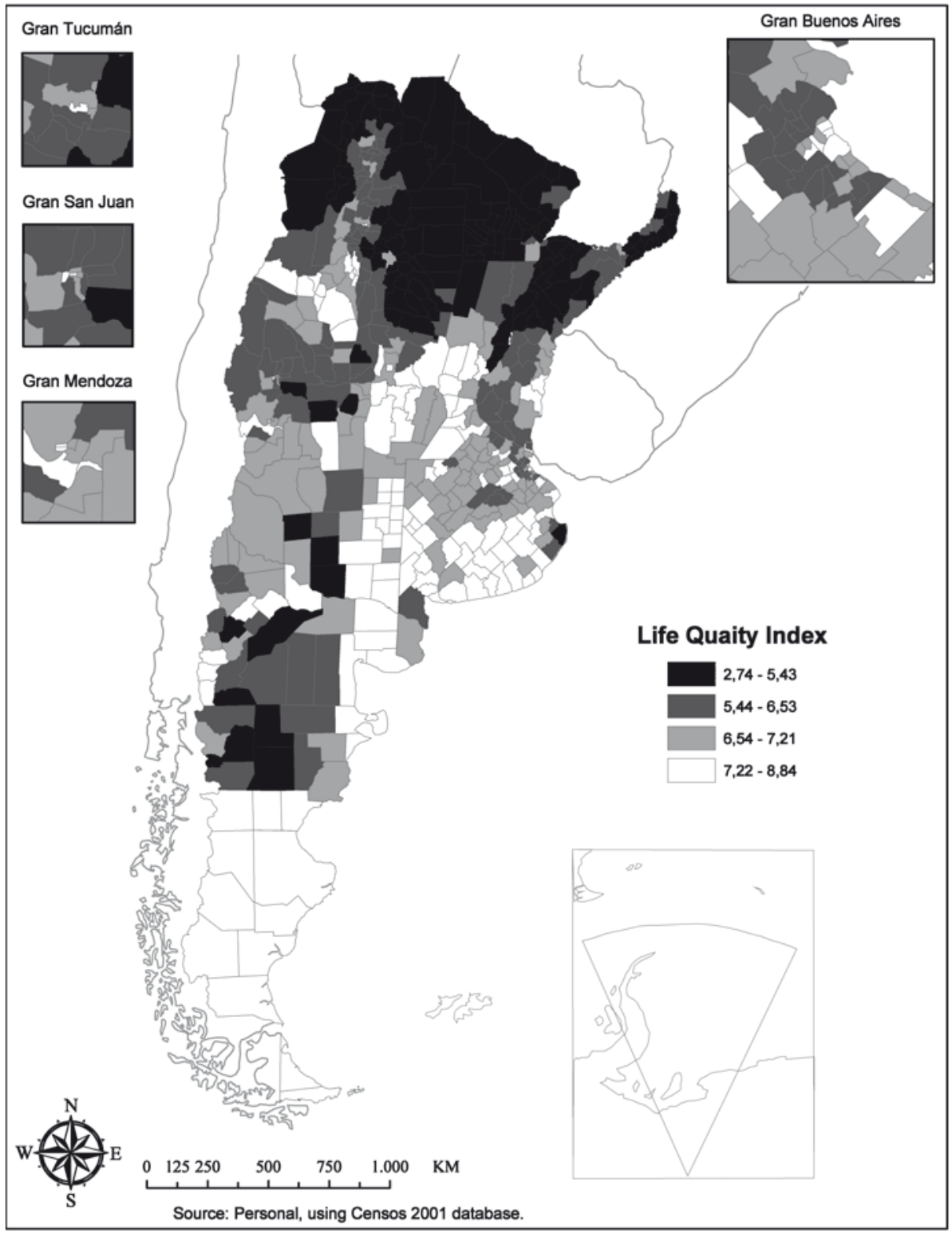

Fig. 8 Life Quality Index, Argentina, c. 2001 


\section{Scenario to future}

It is not very probable that the Argentinian population can emigrate massively due to environmental problems. The most probable scenario is that in the mark of the global heating, the Argentinean territory suffers smaller changes and that it should be adapted to external population's pressure.

The environmental analyzed problems (flood risk, tornadoes, earthquake risk, and soil erosion) have not implied substantial population movements until the present.

The most important factor that affected demographic dynamic has been the regional inequality, related to the "agro-exporter" pattern, the substitute of imports industrialization and the imposition of neo-liberal rules during the nineties.

According to the projection of heating of 4 grades Celcius for the year 2100 (Hulme, 2007) it is expectable that there will be an increment of aridity problems in our territory, fundamentally in the west. These problems could be solved redistributing the industrial water and energetic consumption better, with infrastructure tasks to supply them to residential uses, restricting the sumptuary demand and, at last, with internal population displacements.

\section{References}

Argentina. INDEC (2001): Censo Nacional de Población, Hogares y Viviendas 2001. In www.indec.mecon gov.ar.

CHIOZZA, E., FIGUEIRA, R., IGLESIAS, A. (1987): Territorio. Atlas Total de la República. Argentina. Buenos Aires, Centro Editor de América Latina.

DI PACE, M. (1992): Las utopías del medio ambiente. Buenos Aires, CEAL.

FAO/AGL (2005): National Soil Degradation Maps. In www.fao.org/landandwater/agll/glasod/glasodmaps.jsp. FECIC (1988): El deterioro del ambiente en Argentina. Buenos Aires, FECIC.

GEOSISTEMAS (1997): Mapa de "Riesgos naturales en la Argentina". Buenos Aires.

HOBSBAWM, E. (2000): Entrevista sobre el Siglo XXI. Barcelona, Crítica.

HULME, M. (2007): Climate Change Scenarios for Argentina. In www.cru.uea.ac.uk/ mikeh/research/wwf .argent.pdf

LATTES, A. (1975): Redistribución espacial y migraciones. In Recchini, Z., Lattes, A. (eds.): La población de Argentina. Buenos Aires, CICRED, pp. 95-112.

LATTES, A. (2007): Esplendor y ocaso de las migraciones internas. In Torrado, S Población y bienestar en la Argentina del primero al segundo centenario. Buenos Aires, Edhasa.

LATTES, A., SANA, M. (1992): Los nuevos patrones de la redistribución interprovincial de la población en la Argentina. In $1^{\circ}$ Congreso Nacional de Estudios del Trabajo. Buenos Aires, ASET, 26 al 29 de mayo.

LIBERALI, A., VELÁZQUEZ, G., DiMARCO, A., MATTIELO, A., FERRANTE, E. (1996): Economía, ambiente y salud en la Cuenca del Salado de la Provincia de Buenos Aires. In Primeras Jornadas Nacionales sobre Geografía Física. Bahía Blanca, UNS, pp. 76-81.

LIBERALI, A., MORINA, J., VELÁZQUEZ, G. (1989): Consecuencias socio-ambientales de los cambios en la estructura del empleo. Argentina (1970-1985). In Yanes, L., Liberali, A.: Aportes para el Estudio del Espacio Socio-Económico (III). Buenos Aires, El Coloquio, pp. 57-99.

OTERO, H., VELÁZQUEZ, G. (1995): Tablas de mortalidad de la provincia de Buenos Aires. Tandil, PROPIEP, SECYT UNICEN.

VELÁZQUEZ, G. (2001): Geografía, calidad de vida y fragmentación en la Argentina de los noventa. Análisis regional y departamental utilizando SIG. Tandil, CIG.

VELÁZQUEZ, G. (2008): Geografía y Bienestar. Situación local, regional y global de la Argentina luego del Censo de 2001. Buenos Aires, EUDEBA. 
Introduction: The item explains the relationship among the different variables. We have done the digitization of respective layers of environmental risks and overlap them on an Argentina map, which is divided not also in counties, even in departments (comunas). Migratory dynamics in Argentina through different development stages: This item studies the behaviour of different variables along different historic steps and their influence in migratory dynamics.

Life quality in Argentina: construction of an index: This part are so technical as useful; and at the same time, the central input of a new view about Geography and Life Quality. Natural risks, demographic dynamics and life quality: The maps and tables showed in this item (Flood Risk, Earthquake, Tornadoes, Soil degradation and Life Quality Index) contribute to know, measure present scenarios and prognosticate future ones about population behaviour.

Scenario to future: At the end, we explain our conclusions about present and future in relationship among population behaviour, environmental risks and life quality in Argentina. In this sense, it is not very probable that the Argentinian population can emigrate massively due to environmental problems. The most probable scenario is that in the mark of the global heating, the Argentinean territory suffers smaller changes and that it should be adapted to external population's pressure. The most important factor that affected demographic dynamic has been the regional inequality, related to the "agro-exporter" pattern, the substitute of imports industrialization and the imposition of neo-liberal rules during the nineties. According to the projection of heating of 4 grades Celsius for the year 2100, it is expected that there will be an increment of aridity problems in Argentine territory, fundamentally in the west. These problems could be solved redistributing the industrial water and energetic consumption better, with infrastructure tasks to supply them to residential uses, restricting the sumptuary demand and, at last, with internal population displacements.

Guillermo Angel Velázquez

Director Centro de Investigaciones Geográficas UNICEN Investigador Principal CONICET

Campus Universitario, Paraje Arroyo Seco

Tandil (7000) Buenos Aires

República Argentina

tel.: 542293430912

e-mail:gvelaz@fch.unicen.edu.ar 